\title{
Native Title, land rights and Aboriginal self-determination
}

\author{
Leya Reid
}

University of Technology Sydney, Faculty of Arts and Social Sciences, PO Box 123, Ultimo NSW 2017, Australia. Leya.K.Reid@student.uts.edu.au

DOI: $\quad$ https://doi.org/10.5130/nesais.v4i1.1537

\begin{abstract}
The paper explores the relationship between land rights campaigns and selfdetermination for Indigenous Australians, and argues that Native Title has effectively complicated and undermined the land recovery process that Indigenous Australians achieved under various State land rights acts.
\end{abstract}

Keywords: Land rights, Native Title, self determination

Conflict over resources and their management have been central to the Aboriginal struggle for autonomy and economic self-sufficiency. The land rights movement was a long, historical struggle for 'the return of ancestral lands, or reparation for dispossession (Foley \& Anderson 2006, p.84). Despite fierce opposition from commercial heavyweights and private interests, the campaign successfully captured public support and prevailed over assimilationist attitudes. Led by strong Aboriginal voices, the land rights movement was aptly described by Pickette in 2013 (Cook \& Goodall 2013, p.185) as a 'renewal of the call for self-determination.' When the Native Title Act was passed in 1993, it was upheld as having met the objections of the land justice movement. Contrarily, native title legislation shifted the discourse from the tripartite emphasis on social, cultural and political empowerment that characterised the various land rights acts (Norman 2015) to a narrowed focus on cultural and traditional association to place. Though both pieces of legislation have achieved various degrees of success in terms of securing recognition of prior Indigenous ownership, I argue that native title effectively complicated and undermined the land recovery process that was achieved under the various land rights acts.

Although land rights and native title both pertain to the pursuit of land justice for Indigenous Australians, they are formed from very different socio-political and legal perspectives (Kelly \& Behrendt 2007). The spiritual and custodial link to land is central to Aboriginal existence (Yunupingu 2016; Behrendt 2013) and many Aboriginal leaders recognise the potential for land to empower the Indigenous people to progress towards self-determination and economic self-sufficiency (Laing 2007; Kelly \& Behrendt 2007). Therefore, land demands are driven as much by the need to secure civil and political rights (Norman 2015) as the desire to reclaim land for cultural and traditional significance (Kelly \& Behrendt 2007). Land rights legislation was enacted in response to the ongoing 'social and 
political movement, which evolved from the 1960s to the 1980s' (p. 76) and sought to gain moral and legal recognition of land ownership prior to the dispossession and dislocation of Aboriginal people resulting from European settlement. Under the various Australian jurisdictions, Indigenous people can acquire grants of title for the purposes of protecting 'traditional interests in the land such as heritage or culturally significant sites' (Laing 2007, p.54) or for pursuing 'economic development and social betterment' (p.54). Native title legislation, on the other hand, is the juridical recognition of Indigenous rights to land. Laing (p.54) argues that 'native title is not granted; nor is it a right that has been created by the legislatures, it is about recognising rights that 'have always been there'.'

The modern Australian Aboriginal land rights movement was a sustained campaign driven by Aboriginal voices that demanded the return or compensation of ancestral lands stolen from the dispossessed original owners. At the time, land demands were seen as the best way to advance Aboriginal rights to political and economic self-determination (Foley \& Anderson 2006) and hence became the central political demand. Perhaps the most symbolic development in the Aboriginal land rights movement occurred following Prime Minister McMahon's decision in 1972 to make a public statement rejecting the notion of Aboriginal land rights. Within hours, Sydney protestors assembled on the lawns of Parliament House in Canberra as an 'expression of alienation and rejection of the Australian Government's authority over Aboriginal people' (p.90). The succeeding Whitlam government responded to the pressure of what became known as the 'Aboriginal Embassy' by declaring it would begin discussing models to achieve national land rights (Norman 2015). However, upon recognition that state land laws remained under the sole control of state governments, Aboriginal activists and allies refocused their attention on the potential of state legislation to redistribute state assets and public resources to the original owners (Cook \& Goodall 2013). From 1977 onwards, land rights agitation included strategies such as 'direct action, building alliances and making changes to party policy to force government to take action' (p. 177). In NSW in 1982 the government initiated a Government inquiry, the first stage in the development of a response to the hard-fought political momentum (Cook \& Goodall 2013). The sustained campaign continued to pressure the NSW Government to act on their promise through demonstrated public support, such as the street march organised by the NSW Land Council in 1982, and the bush meetings, which aimed to consolidate consensus amongst Aboriginal communities over strategies for achieving cultural and social goals through land (Cook \& Goodall 2013). By the time the NSW Land Rights Bill was introduced in 1983, the movement had 'successfully captured the popular imagination' (Norman 2015, p.34) and manufactured a 'groundswell of support for the just claims of the land rights movement' (Foley \& Anderson 2006, p.92).

The Australian Federal and State governments reacted to the growing public support for land justice in the mid 1970s by introducing legislation to finally return certain Crown Land to Aboriginal communities. South Australia was the first state government to enact land rights legislation in 1966 with the Aboriginal Lands Trust Act, which consolidated a remaining parcel of Aboriginal reserve lands and placed it under the control of a board of Aboriginal community representatives. In 1972, the Whitlam government established the Aboriginal Land Rights Commission (ALRC), which amongst other things, recommended 'that Aboriginal resources be transferred to Aboriginal ownership in conjunction with the establishment of an Aboriginal Land Commission (Laing 2007, p.52). Subsequently, the Aboriginal Land Rights Act was established in the Northern Territory in 1976. Laing (2007) argues that almost fifty percent of the land in the Northern Territory is collectively owned by Aboriginal people as a result of the land rights legislation. Furthermore, the Land Rights 
Act guarantees that ownership is inalienable other than to the Commonwealth or in the national interest and gives 'traditional landowners the power to regulate access to and use of their land by third parties, including the power to veto mining' (Mowbray 1999, p.9). In NSW, the government enacted the Aboriginal Land Rights Act 1983 (NSW), which allows Indigenous people to claim Crown land as compensation for the deprivation of their land following European invasion. Though the material provisions of the NSW land laws package were only a fraction of what was propositioned by the 1978 Land Rights Inquiry, they significantly marked 'a point of departure from the era of assimilation to one of self-determination' (Norman 2015, p.xxi).

A culmination of the land justice movement, the political process and the resultant legislation in NSW contributed to a dramatic ideological shift necessary for the process of enacting Aboriginal autonomy and economic self-sufficiency. The supersession of the decade long Liberal party rule in 1976 by the Wran Labor Government opened up a window of opportunity for significant reform. Several members in NSW parliament were galvanized by years of the Aboriginal land justice movement and 'were eager to see significant reform, and were now well placed to make this happen' (p.29). The approach taken during the 1978 Land Inquiry revolutionised the way in which the NSW Government consulted Aboriginal people. The Select Committee endeavoured to achieve the full co-operation of the Aboriginal community and enable mutual understanding and knowledge. This was achieved by appointing a representative Aboriginal Taskforce and committing to extensive travel to various locations, documenting and reporting back to Aboriginal Communities, widely promoting submissions and participation, and by enabling maximum accessibility to the Committee's hearings (Norman 2015). The First Report, made public in 1980, acknowledged by introduction 'the violent and bloody history of dispossession experienced by Aboriginal people at the hands of white Australia and the rightful compensation that was due as a result of lost land and culture' (p.47). Norman (p.47) writes that it 'outlined a radical model for the recovery of land, compensation for loss of culture and a representative local community controlled network to advance Aboriginal interests.' The Second Report in 1981 advanced the political vision of the rights to be self-determining. Significantly, the Select Committee's reports framed Aboriginal land rights in relation to both the traditional relationship to country, and as an evolving relationship that continues to develop by virtue of colonisation (Norman 2015). Though discriminatory laws and practices continue to disproportionately impact Aboriginal communities, the land rights movement insured a genuine undertaking from the government to abandon assimilationist attitudes.

While the various land rights acts were configured in social justice terms with a vision for social, cultural and economic betterment, the recognition of Native Title placed a much greater emphasis on cultural association (Norman 2015). In 1993, the Australian Government enacted legislation to administer native title claims. The Native Title Act 1993 was a result of the Mabo decision, which for the first time overturned the fictional declaration of 'terra nullius' and asserted the secure tenure for Aboriginal people that have retained their connection to alienated lands (Behrendt 2013). The High Court found that rather than being 'automatically extinguished by the acquisition of sovereignty by the British' (Behrendt \& Kelly 2008, p. 3), native title survived and continues to exist provided 'that it was not otherwise extinguished by legally valid, inconsistent grants of land by the government' (p. 3). Heralded as a judicial revolution (Strelein 2009), the decision in Mabo and subsequent Native Title legislation can be accredited for prompting anthropological investigations and reports on connection to country, which duly has the potential to 'foster respect for traditional knowledge holders, and perhaps revitalise traditional culture' (Behrendt and Kelly 2008, p.ix). More so however, the Native 
Title has come under heavy criticism for the weakness of the titles it administers and for abandoning the goal previously pursued by land laws of providing economic development (Behrendt 2013). Norman (2015, p.xviii) argues that in NSW, the Native Title Act 'challenged the legitimacy and significance of the land laws' and members of the Land Council met this with great skepticism. Though Native Title laws have been accepted by some as a starting point to achieving reconciliation between Aboriginal people and the nation state (Borsboom 2012), Native Title ushered in a departure from the land laws' commitment to honour both traditional association to place and the potential of land to empower economic, social and political participation.

The complexity and excessively elaborate legal process of making native title claims, as well as the subordinate and weak nature of the title means that the legislation benefits very few. Rather than obtaining title deeds or exclusive land ownership through native title determinations, native title claimant groups are 'simply having their pre-existing rights (that have been there for generations) recognised in the Australian legal system' (Laing 2007, p.54). Native title claims are often mediated to have non-exclusive or co-existing rights with other interested parties. The court process and determination of native title does not diminish or interfere with the rights of other people in the claimed area, including the interests of non-Indigenous parties or companies (Laing 2007). Furthermore, many Aboriginal people have encountered frustration and difficulty navigating the legal process of proving that they have an enduring knowledge or observation of the laws and customs of their ancestors in respect to the claimed land. A native title claimant group 'must demonstrate that it has common or group rights and interests in the claimed area under traditional laws and customs' (Lavery 2004, p.2) however the act itself fails to provide guidance as to what constitutes a native title claim group. The process of making a claimant application, including non-claimant applications or applications for compensation, requires basic legal knowledge surrounding native title, making it particularly prohibitive for those without formal education on court practices, procedures and principles (Laing 2007).

The decision of the High Court against the Yorta Yorta people in Members of the Yorta Yorta Aboriginal Community v Victoria (2002) demonstrates the difficulty of proving continuous connection to country. Upon appeal to the Federal Court in 1995 following a failure to mediate an agreement between the Yorta Yorta claimant group and over 400 non-Indigenous interested parties, the court ruled that 'despite ongoing physical presence, assertation of rights to the land, maintenance of identification as a community entitled to the land and maintenance of cultural identity... the Yorta Yorta people did not continuously occupy the land in the relevant sense' (Strelein 2009, p.75). The Yorta Yorta case underwent nine years of the due Native Title process, only for the High Court to hand down its dismissal of the appeal. This exemplifies the onerous burden of navigating a slow and complicated process especially because native title bodies are often under-resourced and have limited budgets. The capacity of native title to fulfill the aspirations of Indigenous people is doubtful given the requirements of proof are complex and often subject to authoritative interpretation and decisionmaking.

The Mabo Decision and subsequent Native Title Act have effectively officiated the dispossession of the majority of Indigenous Australians by prioritising corporate interests. The rights of native title claimants are vulnerable to the doctrine of extinguishment. Strelein (2009, p.16) writes that 'the colonies, and later the states and Commonwealth had the power to abrogate the rights of Indigenous peoples for the private benefit non-Indigenous settlers.' As a 'clear assertion of colonial sovereign 
power' (p.17), the court ruled that the Crown 'has the power to extinguish title unilaterally (that is, without consent) by legislation or by executive act' (p.17). Whereas the right to veto commercial development was an intrinsic component of the Northern Territory and NSW Land Rights legislation, the application of native title gave way to the 'interests of a powerful commercial lobby with the aid of a constructed national crisis of uncertainty and a sympathetic press' (Short 2016, n.p.). Recent amendments to the Native Title Act in 2017 demonstrate that the legislation is simply 'a governmental instrument used at whim to achieve dispossession through 'legal means'... and ameliorate mining interests against the traditional custodians of the land' (Cromb 2017, para 19). By removing the requirement for all traditional owners to approve future agreements, the government is permitting the Adani mine, one of the largest and most destructive in the world (Brevini \& Murdock 2017), to proceed despite a legitimate Native Title claim. The statutory process of Native Title prioritises nonIndigenous titles and rights, leaving Indigenous recognition forestalled by complex legal and doctrinal obstacles.

If we were to acknowledge that Aboriginal communities are empowered when they have the ability to exercise control over their own affairs and that land can form the basis for economic independence (Behrendt \& Kelly 2008), then clearly the land rights movement made a huge leap towards enacting Aboriginal self-determination and self-sufficiency. However, by no means can we attribute Native Title legislation to having improved the economic, social and cultural participation for a majority of the Aboriginal population. To the contrary I have argued that the Mabo Decision and subsequent Native Title Act significantly obstructed the achievements of the otherwise successful political struggle of the land rights movement. Despite this, the land rights movement persists. Separate from native title, there have been two lots of handbacks to Tasmanian Aboriginal communities: 3900 hectares were handed back under a conservative government in 1995, and in 2005 a Labor Government returned the ownership of Cape Barren, Goose and Clarke Islands (Foley \& Anderson 2006). The challenge into the future is to sustain the land rights movement while navigating the increasingly bureaucratic control of Aboriginal affairs.

\section{Reference List}

Behrendt, L. 2013, 'Land rights and native title', Hot Topics: Legal Issues in Plain Language, no. 86, pp. 16-19.

Behrendt, L. \& Kelly, L. 2008, Resolving Indigenous Disputes: Land Conflict and Beyond, Federation Press, Sydney.

Benedetta, B \& Murdock, G. 2017, Carbon Capitalism and Communication: Confronting Climate Crisis, Springer, Cham.

Borsboom, A. 2012, 'From Terra Nullius to Mabo: Land Rights and Self-determination in Aboriginal Australia', in T. van Meijl \& F. von Benda-Beckmann (eds), Property Rights \& Economic Development, Routledge, New York, pp. 208-228. 
Cook, K. \& Goodall, H. 2013, Making Change Happen: Black and White Activists talk to Kevin Cook about Aboriginal, Union and Liberation Politics, ANU Press, Canberra.

Cromb, N. 2017, 'Native Title is not 'land rights", National Indigenous Television, 22 June, viewed 25 June 2018, <https://www.sbs.com.au/nitv/article/2017/06/22/native-title-not-land-rights $>$.

Foley, G. \& Anderson, T. 2006, 'Land Rights and Aboriginal Voices', Australian Journal of Human Rights, vol. 12, no. 1, pp. 83-108. https://doi.org/10.1080/1323238X.2006.11910814

Kelly, L \& Behrendt, B. 2007, 'Creating Conflict: Case Studies in the tension between native title claims and land right claims', The Journal of Indigenous Policy, no. 8, pp. 73-102.

Laing, N. 2007, 'Distinguishing native title and land rights: not an easy path to rights or recognition', The Journal of Indigenous Policy, no. 8, pp. 50-72.

Lavery, D. 2004, 'Issues of Native Title', Land, Rights, Laws, vol. 2, no. 30, pp. 1-12.

Mowbray, M. 1999, 'Redefining Land Rights: The Review of the Aboriginal Land Rights (Northern Territory) Act 1976', Indigenous Law Bulletin, vol. 4, no. 18, pp. 9-12.

Norman, H. 2015, 'What Do We Want?': A Political History of Aboriginal Land Rights in New South Wales, Aboriginal Studies Press, Canberra.

Short, D. 2016, Reconciliation and Colonial Power: Indigenous Rights in Australia, Routledge, New York. https://doi.org/10.4324/9781315603933

Strelein, L. 2009, Compromised Jurisprudence: Native Title Cases Since Mabo, 2nd edn, Aboriginal Studies Press, Canberra.

Yunupingu, G. 2016, 'Rom Watangu', The Monthly, July, viewed 7 April 2018,

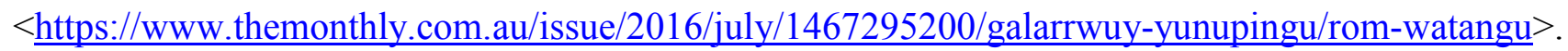

(C) 2018 by the author(s). This article is distributed under the terms and conditions of the Creative Commons Attribution license (http://creativecommons.org/licenses/by-nd/4.0/). 